\title{
"SINCERAMENTE, SUA": CARTAS ANÔNIMAS EM ROSARIO FERRÉ
}

\author{
Stelamaris Coser
}

\begin{abstract}
RESUMO
Após breve análise do gênero epistolar e a especificidade da carta anônima, com exemplos da literatura brasileira, focalizam-se as cartas inseridas no conto "La bella durmiente"/“Sleeping Beauty”, de Rosario Ferré (original 1976). Conjugando análise textual e contextualização sociocultural, este trabalho associa as cartas anônimas à condição feminina e à situaçáo marginal de Porto Rico como estado/nação.
\end{abstract}

PALAVRAS-CHAVE: "La bella durmiente", carta anônima, feminino.

When my love swears that she is made of truth I do believe her though I know she lies William Shakespeare, Soneto 138

Uma carta traz vivas marcas do ausente, o cunho autêntico de sua pessoa. Sêneca ${ }^{1}$ escoberta por Colombo e reivindicada pela Coroa espanhola desde 1493, a ilha de Porto Rico ${ }^{2}$ foi cedida pela Espanha aos Estados Unidos em 1898, quando o antigo colonizador europeu perdeu a guerra e

1 SÊNECA apud SUSSEKIND, Flora. Cabral-Bandeira-Drummond. A voz e a série. Belo Horizonte: Sette Letras: UFMG, 1998. p. 263.

2 Chamada Barikén pelos indígenas aruaques que a habitavam, foi a princípio denominada Ilha de San Juan Baptista por Colombo, nome depois encurtado para designar a capital, San Juan. 
a disputa pelos territórios sob seu domínio, sendo substituído pelo novo poder imperial que se impunha. Com localização privilegiada (e cobiçada) entre o Oceano Atlântico e o Mar do Caribe, a ilha (que integra um arquipélago de várias pequenas ilhas) é considerada, desde 1952, parte dos Estados Unidos na condição ambígua de Estado Livre Associado, território dependente e sem caráter jurídico preciso, nem estado nem país com legitimidade clara. Um espaço que interessa ao centro hegemônico e, ao mesmo tempo, o incomoda, com um povo e uma cultura cuja identidade escapa a classificaçóes nítidas, homogêneas e padronizadas.

De certa forma, as cartas anônimas, em foco neste trabalho, compartilham algumas das características que acabam de ser atribuídas ao contexto porto-riquenho: certa conotação de ilegitimidade ou desprestígio e a marginalização dentro de padróes estabelecidos que, no caso das cartas, são as linhas delimitadoras do gênero epistolar. Esse gênero se encontra nas bases fundadoras da ficção europeia, no século XVIII, com grandes nomes, como Richardson, Rousseau e Goethe, entre outros, e vem sendo periodicamente retomado, adaptado e renovado por autores dos mais variados estilos e procedências. As cartas anônimas, como ilustram as que se destacam no conto "La bella durmiente"/"Sleeping beauty", da escritora porto-riquenha Rosario Ferré, seguem o formato básico de uma carta comum ao conterem destinatário, endereçamento, local e data, uma saudação e o texto da missiva escrito em primeira pessoa. Contrastam, porém, pela falta de assinatura e identificação de um remetente explícito, proporcionando efeitos de mistério e suspense, para o leitor, e ameaça, medo e/ou ódio, para o personagem receptor, além de levantar dúvidas sobre o estatuto de "registro de indiscutíveis verdades" ${ }^{3}$ que costuma ser imputado às cartas pessoais. ${ }^{4}$

\section{De...... Para......: As cartas e suas características}

Para assegurar privacidade e confiabilidade, uma carta é normalmente colocada em envelope endereçado, fechado e selado e, em lugar dos antigos

3 Termos usados em PERES, Ciomara Breder. Remexendo cartas novas e velhas, encontrando o inesperado: uma análise comparativa de Mariana, Ovídio e as três Marias. http://www.ufop. br/ichs/conifes/anais/LCA/lca2903.htm. 10/09/2002.

4 Por questão de espaço e foco, o recorte escolhido para este trabalho limita-se a cartas no formato tradicional. 
mensageiros, é enviada através de serviço postal regulamentado por lei contra possível violação, dano ou subtração. Mesmo assim, seu percurso não difere de outras viagens; pode apresentar atropelos e ambiguidades e suscitar dúvidas e disputas, como, por exemplo, até quando o autor/remetente é "dono" da carta e poderá reinvindicá-la. No artigo "A quem pertence uma carta?", Lejeune aborda controvérsias legais envolvendo cartas comuns, mas nelas há sempre pelo menos duas pessoas geograficamente separadas, um remetente, de um lado, e um interlocutor/destinatário, de outro. ${ }^{5}$

$\mathrm{O}$ uso do formato epistolar, onde a primeira pessoa, o eu que escreve e assina o texto, interpela o outro que recebe e lê a carta, contribui para a impressão de sinceridade ou autenticidade do que é revelado. Não surpreende o fato de a ficção ter-se alimentado tanto da epistolaridade, já que também deseja obter a confiança do leitor. Käte Hamburger argumenta que a essência da ficção literária é "parecer como realidade" (como disse Theodor Fontane, por ela citado, já em 1875), conseguir mostrar aparência de real por meio do enunciado. Ao realçar a ilusão do real, a narrativa em primeira pessoa é um dos recursos adotados por escritores para induzir o leitor a acreditar naquilo que lê. $\mathrm{O}$ efeito se intensifica se o sujeito aparece como eu e enuncia o real numa carta, já que, como ressalta Hamburger, a percepção comum assevera que "a carta é sempre um documento histórico, que testemunha sobre uma pessoa individual". ${ }^{6} \mathrm{O}$ escritor Luiz Ruffato comenta esse efeito de suposta transparência alcançada pelo gênero epistolar, ainda mais eficaz que o mero uso do narrador em primeira pessoa: "A narrativa tradicional, mesmo em primeira pessoa, é seletiva - o leitor desconfia que o autor está escondendo algo dele. Na epistolografia, não, a sensação é de que nada nos está sendo omitido". ${ }^{7}$

Em conhecida obra sobre as características do gênero epistolar na literatura, Janet G. Altman (1982) define "epistolaridade" como o conjunto

5 LEJEUNE, Phillipe. O pacto autobiográfico: de Rousseau à Internet. Org. Jovita G. Noronha. Belo Horizonte: UFMG, 2008. p. 253.

6 HAMBURGER, Käte. A lógica da criação literária. São Paulo: Perspectiva, 1975. p. 24-41 (Coleção Estudos).

7 RUFFATO apud CARPINEJAR, Fabrício. "Um amor por escrito". Revista da Cultura, 12, São Paulo, julho 2008. http://www2.livrariacultura.com.br/culturanews/rc12/index2. asp?page=reportagem $01.25 / 07 / 2008$. 
de fatores que confere significado à obra de ficção através da aplicação de "estruturas e do potencial específico da carta", ainda que a obra não seja construída primordialmente com base em cartas e se desvie do entendimento tradicional de "romance epistolar". ${ }^{8}$ Altman ressalta os efeitos de envolvimento e complexidade conseguidos pelo escritor ao explorar níveis variados de confiança quando o destinatário é tratado como confidente (de tipo amigo ou amoroso), alguém que o remetente procura seduzir para algum tipo de projeto ou parceria. Na carta anônima, pode-se acrescentar aqui, o remetente tenta colocar-se como simpatizante ou amigo do destinatário, a quem trata como confidente escolhido para ouvir um segredo, procurando seduzi-lo com astúcia e induzi-lo a uma ação decorrente da leitura do texto revelador. ${ }^{9}$

Como recurso literário, ainda segundo Altman, o uso das cartas pode sugerir um jogo de enganos e dissimulaçóes, de modo que a diferença entre amigo e amante, por exemplo, se torne confusa e ambivalente, ou que, em outro contexto, um estranho ou inimigo se passe por solícito confidente. As cartas do tipo confessional, que revelam algum segredo importante, são sempre fonte de suspense e interesse na literatura de caráter epistolar. Outra característica da carta apontada pelo filósofo Rubem Alves é o caráter de objeto concreto e palpável que a diferencia do telefonema, por exemplo. Ao comentar o quadro de Vermeer "A mulher que lê", Alves observa como a carta de amor pode ser marca de presença carinhosamente tocada e preservada:

[...] a mulher tem nas mãos uma carta. A carta é um objeto. Se não tivesse podido recolher-se à sua solidão, ela poderia tê-la guardado, no bolso, na deliciosa espera do momento oportuno. O telefone não pode esperar. A carta é paciente. Guarda as suas palavras. E, depois de lida, poderá ser relida. Ou simplesmente acariciada. Uma carta contra o rosto poderá haver coisas mais eterna? Uma carta é mais que uma mensagem. Mesmo antes de

8 ALTMAN, Janet Gurkin. Epistolarity: approaches to a form. Columbus: Ohio State University, 1982. p.5, 48-49, 60-71. https://ohiostatepress.org/index.htm?/books/book pages/ altman epistolarity.html. 21/12/2011.

9 A tradução livre de trechos de obras originalmente em língua inglesa ou espanhola, aqui citados em português, é de responsabilidade da autora deste artigo. 
ser lida ainda dentro do envelope fechado, tem a qualidade de um sacramento: presença sensível de uma felicidade invisível. ${ }^{10}$

Sentimento bastante oposto ao descrito é aquele despertado por uma carta anônima acusatória que incita ódio e vingança. De toda maneira, cartas recebidas podem ser roubadas e desviadas, como no conto de Poe, ${ }^{11}$ amassadas, rasgadas, descartadas, ou guardadas e relidas, à espera de alguma reação do leitor/receptor.

O gênero discursivo carta, aqui pensada como interlocução que se serve da linguagem escrita para envio de uma mensagem, apresenta variaçóes em relação a aspecto formal, nível de tratamento, objetivo, modo de envio e recepção. Assim, temos bilhetes, lembretes, cartóes postais, cartões de cumprimento, convites etc. ${ }^{12}$ Há, certamente, as "cartas abertas" de explicação, protesto ou denúncia publicadas em jornais e endereçadas, de forma pública, a todos os leitores; existem cartas comerciais, oficiais, políticas e profissionais, que seguem padróes formais de maior rigidez e afastam-se da suposta espontaneidade das cartas pessoais. Quanto a estas, o senso comum e a curiosidade do voyeur tendem a julgar a correspondência como algo "fascinante por revelar o que há de mais recôndito em cada um", já que "o conteúdo de uma carta re-

10 ALVES, Rubem. Cartas de amor. In: O retorno e terno. Campinas: Papirus, 1994. http://www.freeblog.com.br/flordelotusnamaste/2164/Cartas+de+Amor+-+Rubem+Alves. html.

29/09/2008. Em entrevista em 2008, Alves acrescenta a fisicalidade aproximada dos amantes como a essência da carta de amor, o toque ou contato procurado através do papel: "As informaçóes não têm a menor importância, porque elas não fazem parte da essência da carta de amor. O que faz uma carta de amor é o fato de que um tocou aquela folha e o outro vai tocar a mesma folha de papel. Assim, você toca a carta, mas o outro não está lá. É por isso que a carta de amor tem essa beleza triste." http://samacc.wordpress.com/2008/07/22/para-minha-sister/. 29/08/2008.

11 POE, Edgar A. A carta roubada. Ficção Completa, Poesia \& Ensaios. Org. Oscar Mendes; Colab. Milton Amado. Rio de Janeiro: Aguilar, 1965 (Título original: "The purloined letter”, 1844).

$12 \mathrm{Na}$ epistolografia pode-se considerar também o diário íntimo, forma que se distingue por ser supostamente escrita para si mesmo e não para um interlocutor, ou seja, por não conter a ideia de envio e intercomunicação, embora haja controvérsia crítica a respeito. Sobre a criação de diários ficcionais em obras das escritoras de origem caribenha Maryse Condé e Cristina Garcia, COSER, Stelamaris. Reescrevendo gêneros: o feminino, o diário e a nação. Revista Brasileira do Caribe, Brasília, v. 9, n. 17, p.165-196, jul.-dez. 2008. 
vela mais sobre seu remetente do que qualquer outra coisa que já se tenha dito sobre ele"13. Teóricos das últimas décadas, no entanto, têm problematizado com frequência a representação do "real" e do "autêntico". No livro La carte postale, originalmente publicado em 1980, por exemplo, Derrida desconstrói e fragmenta o formato epistolar, jogando com suas (im)possibilidades, seus envios e desvios para, afinal, questionar autor, autoridade, identidade e verdade, princípios básicos da filosofia ocidental. ${ }^{14}$ No formato e expectativa tradicionais, contudo, a carta anônima seria aquela que sempre aponta o ausente, a des-autorização, a falta da confiabilidade, do aval e da presença de um assinante ou signatário.

\section{Para ... : A carta anônima}

Mas depois sou eu quem dorme e sonha, sonho com os anjos. Nuvens, espaços azuis, pérolas no fundo do mar. Clack! como se fosse verdade, um beijo

Caio Fernando Abreu, "Carta anônima"15

Os escritores de cartas anônimas se escondem no vazio, fingindo-se de ninguém: querem enviar sua mensagem, por provável vingança ou intenção de provocar cizânia e estrago em outros, mas de modo a não atrair ira ou vingança sobre si mesmos. No ato de esconder-se, o remetente anônimo também distorce e nega o intercâmbio geralmente articulado pelas cartas. Um lugar passivo e inerte é agora imposto ao destinatário, que não se pode tornar remetente, desprovido do direito de enviar uma resposta pela falta de nome e destino passível de ser endereçado. Desvirtua-se, assim, o papel ou a função da carta, que seria prosseguir em seu trajeto e produzir comunicação. A repetição da mensagem anônima, por outro lado, reitera e insiste na veracidade da

13 CLOSA, Luciana. As correspondências na literatura. Cultura-e: Revista Veredas, n. 73, jan. 2002. http:/www.cultura-e.com.br/Site/rvsVer/Edicao73/Not012.asp. 10/09/2002.

14 Em tradução brasileira: DERRIDA, Jacques. O cartão-postal-de Sócrates a Freude além. Rio de Janeiro: Civilização Brasileira, 2007.

15 ABREU, Caio Fernando. Carta Anônima. http://fadasefool.blogspot.com/2007/12/carta-annima-caio-fernando-abreu.html. 27/02/2012. 
informação sigilosa, pressionando o receptor a reagir em nome da (suposta) moral e justiça.

A título de ilustração e contraponto, este preâmbulo introdutório relembra alguns registros da literatura brasileira que ilustram o uso estratégico de cartas anônimas no desenvolvimento da trama ficcional. Autores consagrados, como Machado de Assis, Graciliano Ramos e Nelson Rodrigues, em tempos históricos diversos, utilizam a carta anônima como fator propulsor do conflito central. Machado joga ironicamente com a hipocrisia social no conto "A senhora do Galvão" (original de 1884), no qual várias cartas anônimas reiteram à esposa Maria Olímpia a traição do marido, o advogado Galvão, com sua amiga, a viúva do brigadeiro. ${ }^{16} \mathrm{~A}$ referência insistente aos importantes cargos masculinos, sublinhada pelo lugar dependente da mulher como mera esposa ou viúva, contribui para a construção sutil do contexto social e a satirização de padrôes morais. Os personagens envolvidos nessa situação triangular preferem manter as aparências e abafar qualquer reação violenta, de modo que o casamento é mantido e ocorre apenas uma separação "amigável" entre as ex-amigas. O leitor é instigado pelo mistério que envolve a autoria da cizânia: teria sido a viúva a autora das cartas anônimas, visando exatamente a separar o casal e a roubar o marido da suposta amiga?

Em contrapartida, no conto "A cartomante", também de Machado (1884), o personagem Vilela é traído pela esposa Rita, que tem um caso com o melhor amigo dele, Camilo. ${ }^{17}$ É este quem recebe cartas anônimas acusatórias, mas não as leva a sério; o resultado é que o casal de traidores, Rita e Camilo, acaba assassinado pelo marido desesperado. ${ }^{18} \mathrm{O}$ texto deixa entrever a possibilidade de que o próprio marido teria tentado anonimamente afastar o rival por meio das ameaças morais expressas na carta anônima. Em Caetés, primeiro romance de Graciliano Ramos (originalmente publicado em 1933), a tragédia também acompanha a traição narrada. Uma carta anônima denuncia a Adrião

16 ASSIS, Machado. A senhora do Galvão. In: Volume de contos. Rio de Janeiro: Garnier, 1884. http://www.eurooscar.com/Machado-de-Assis/Machado-de-Assis-20.htm. $15 / 12 / 2011$.

17 ASSIS, Machado. A cartomante. In: Obra completa. V. II. Rio de Janeiro: Nova Aguilar, 1994.

18 Ver artigo crítico de CARNEIRO, Flavio. O leitor e a morte. http://www.dubitoergosum.xpg.com.br/convidado07.htm. 15/12/2011. 
o caso amoroso entre sua esposa Luisa e João Valério, seu colega de trabalho e protegido, o que acaba provocando grande desilusão e o suicídio do marido, além de direcionar os desenvolvimentos a seguir. ${ }^{19}$

Somando humor e ironia a toques de perversão nas relaçóes conjugais e familiares, diversos contos de Nelson Rodrigues utilizam cartas anônimas com efeito surpreendente. ${ }^{20}$ Em "Casal de três", por exemplo, o marido Filadelfo observa com aprovação a nova sensualidade da mulher Jupira, antes relaxada e geniosa. Quando recebe uma carta anônima denunciando que ela o traía com Cunha, seu amigo íntimo, o marido prefere manter o triângulo que o tem feito feliz, obrigando o "rival" a dedicar-se rotineiramente a Jupira e a jantar com o casal. No conto "O decote", tanto uma carta anônima quanto a sogra de Clara denunciam a infidelidade da mulher a Aderbal, marido farrista e muito ligado à filha. Ele só mata a esposa quando a própria filha lhe diz que "não gosta mais da mãe"... Em "A humilhada", telefonemas e cartas anônimas relatam a Regina as muitas traiçóes do marido Guilherme; a filha, neste caso, estimula a mãe a revidar também com traição. ${ }^{21} \mathrm{~A}$ intenção supostamente conservadora e moralizadora das cartas anônimas é desestabilizada pelo deboche à hipocrisia das relaçóes e costumes burgueses.

Nesta breve ponte com a literatura brasileira, observam-se algumas variações e sutilezas no uso literário da carta anônima, que, ainda assim, subscreve o padrão convencional que supóe um conteúdo denunciador e desestabilizador, um destinatário expresso, e a ausência da assinatura que revelaria e autorizaria o remetente, responsável pelo conteúdo da carta e pelas consequências daí advindas. Endereçada ao cônjuge traído ou ao personagem traidor, as cartas movimentam e tensionam textos inspirados na infidelidade conjugal e nas contradiçóes humanas, deixando ao leitor dúvidas e especulaçóes sobre a autoria e os possíveis interesses atrás do anonimato.

19 RAMOS, Graciliano. Caetés. (1933). São Paulo: Martins, 1969.

20 In: RODRIGUES, Nelson. A vida como ela é...: O homem fiel e outros contos. $14^{\mathrm{a}}$ reimpressão. São Paulo: Companhia das Letras, 1992.

21 Os contos de Rodrigues são comentados em ZECHLINSKI, Beatriz Polidori. “A vida como ela é...”: imagens do casamento e do amor em Nelson Rodrigues. Cadernos Pagu, 29:399-428, Campinas, jul/dez 2007. http://www.scielo.br/scielo.php?pid=S0104$-83332007000200016 \&$ script=sci_arttext. 15/12/2011. 


\section{Rosario Ferré e "La Bella Durmiente"22}

Tú bailas la ira cantando Una ira larga y roja como tu corazón Rosario Ferré, "La bailarina"

Nascida em 1938 na cidade de Ponce, ao sul da ilha, Rosario Ferré é uma das escritoras mais representativas de Porto Rico; sua obra conjuga trabalhos jornalísticos, traduçóes, ensaios, relatos autobiográficos, poesia, contos e romances inspirados pela história e cultura porto-riquenha. Como atesta Carmen Dolores Hernández, o trabalho de Ferré como editora e escritora na revista Zona carga y descarga e suas publicaçōes individuais expóem "os conflitos internos da sociedade estabelecida: suas contradiçōes e fissuras". Jovem pertencente à elite social e cultural da ilha e integrante da chamada "Geração de 1970", Ferré realmente "escreveu "a partir de dentro" da classe alta [...], ficçóes que documentaram literariamente o mundo privilegiado". ${ }^{23}$ Recebe influências cruzadas do socialismo cubano, do feminismo, e da literatura do chamado Boom latino-americano (do qual Ferré se aproxima como aluna de Angel Rama e Mario Vargas Llosa no mestrado na Universidade de Porto Rico, e aprofundando-se em Julio Cortázar em tese de doutorado na Universidade de Maryland).

O conto "La bella durmiente" foi publicado originalmente em espanhol em 1976, incluído na sua primeira coletânea de contos, Papeles de Pandora. Traduzido e adaptado para a língua inglesa pela autora com Diana L. Vélez, o texto foi publicado com o título de "Sleeping Beauty", na revista Feminist Studies (1986) e em coletânea de contos de escritoras porto-riquenhas, organizada por Vélez (1988 e 1997). Uma nova versão inglesa

22 Este estudo retoma trabalhos anteriores voltados para a questão de gênero, os balés/ performances e o entrelaçamento histórico: COSER, S. Papéis femininos em Rosario Ferré. In: Machado, Lino et al. Pessoa, persona, personagem. Vitória ES: PPGL, 2009. p. 315-326; e COSER, S. Escrevendo a nação no feminino: ficção e história. In: XIII CONGRESSO DE ESTUDOS LITERÁRIOS, 2011, UFES, Vitória ES. Que autor sou eu?: deslocamentos, experiências, fronteiras; Programação e resumos. Vitória: PPGL/UFES, 05 a 07 outubro 2011. p. 14,16 .

23 HERNÁNDEZ, Carmen Dolores. Rosario Ferré. A viva voz: entrevistas a escritores puertorriqueños. San Juan: Grupo Editorial Norma, 2007. p. 94. 
produzida por Ferré e Vélez foi inserida na tradução de Papeles de Pandora para o inglês, livro intitulado The youngest doll (1991) como o primeiro conto do volume. ${ }^{24}$

"La bella durmiente"/“Sleeping Beauty" evoca de imediato o conhecido conto de fadas de Charles Perrault e o famoso balé russo musicado por Tchaikovsky. Além desta, outras duas peças do balé romântico europeu do século XIX, Copélia e Giselle, ${ }^{25}$ são dançadas no palco ou nos delírios de Maria de los Angeles, a jovem protagonista-bailarina. Caracterizada por grande beleza e plasticidade, mas também pela opressão e morte de figuras femininas, o balé clássico apresentado no teatro de prestígio na cidade de San Juan tem contrapartida no circo e nos ritmos hibridizados da população negra ou mulata e pobre, estes apenas imaginados à distancia e mantidos à margem do texto, devidamente silenciados pelo poder hegemônico. Maria é moça rica, filha do prefeito de San Juan, Don Fabiano Fernández, educada em escola de freiras com o objetivo de ser corretamente moldada pelos limites de classe, raça e gênero ensinados no discurso cristão arcaico e nos padróes patriarcais. Mesmo a dança clássica lhe é vetada pelos perigos que supostamente oferece a uma donzela aristocrática. Privada da sensação de beleza, harmonia e liberdade que a dança lhe proporcionava, Maria acaba destruída pelas normas e proibiçóes do controle familiar, social e religioso e pela violência em seu próprio contexto familiar. Adoece, delira, torna-se apática e refugia-se nas lembranças de infância e na imagem da equilibrista de nome Carmen Merengue, ex-amante de seu conceituado pai. A princesa de vestido branco gostaria, talvez, de transformar-se na rebelde cigana Carmen, de vestido vermelho e sensualidade escancarada. ${ }^{26}$ Ousando ir além, a moça rica e católica acaba tomando para si o papel de prostituta-equilibrista, pobre e

24 As três versões do conto aqui referidas são: FERRÉ, Rosario. La bella durmiente. In: Papeles de Pandora. 1976. Nova York: Vintage Español, 2000. p. 149-191; FERRÉ, Rosario. Sleeping Beauty. In: VÉLEZ, Diana L.(Ed.). Reclaiming Medusa: short-stories by contemporary Puerto Rican women. Rev. ed. San Francisco: Aunt Lute, 1988, 1997. p.12-41; FERRÉ, Rosario. Sleeping Beauty. In: The youngest doll. Lincoln \& London: University of Nebraska, 1991. p. 89-120.

25 Copélia é adaptação do conto "O homem de areia" (1815) de E. T. A. Hoffmann, e Giselle tem libreto de Théophile Gautier inspirado por Heinrich Heine’s De l'Allemagne.

26 A ópera Carmen, de Georges Bizet, tem libreto inspirado em novela de Prosper Merimée. 
mestiça, incorporando a amante do pai para afrontar seus opressores. ${ }^{27}$

Paralelamente à fragmentação psicológica da silenciosa protagonista, o próprio texto se esfacela em divagaçóes e memórias entrecortadas de Maria (destacadas em itálico nas ediçôes em inglês), junto a recortes, notícias e cartas diversas, cujas datas, destinatários e remetentes podem auxiliar o leitor a entender a sequência e os hiatos entre acontecimentos. Três colunas sociais do jornal Mundo Nuevo (no original espanhol e na primeira tradução para o inglês) ou El Mundo (versão 1991), inseridos no conto, apresentam relatos prolixos de momentos recentes na vida da protagonista. A primeira descreve Maria de los Angeles no palco dançando Copélia, fugindo inesperadamente para a rua, mas voltando para concluir brilhantemente o espetáculo; outra fala do compromisso firmado entre ela e o noivo Felisberto Ortiz e da expectativa de um casamento de altíssimo nível; a terceira descreve a cerimônia e a festa do casamento marcada por grande luxo. Dedicados à moça pela prestimosa mãe Elizabeth e colados em seu álbum de casamento, encontram-se recortes de revistas com dicas para o chá da noiva ("el shower", termo inglês usado no original espanhol, certamente considerado mais elegante); regras sobre as melhores louças, pratarias, cristais, roupas de cama, mesa e banho; conselhos para a felicidade da boa esposa e mãe cristá; legendas sentimentais e piedosas escritas pela mãe entusiasmada sob fotos no álbum de casamento; e, por fim, o anúncio divulgando o nascimento de Fabianito Ortiz Fernández.

Contribuem primordialmente para a multiplicação de pontos de vista e a construção fragmentada do texto as dez cartas integralmente transcritas (cinco enviadas pela Madre Martínez, superiora do Colégio Sagrado Coração de Jesus, sendo quatro para Don Fabiano e uma para a jovem Maria; quatro cartas de Don Fabiano para a Madre; e uma carta sendo escrita e não terminada por Felisberto, marido de Maria, e dirigida ao sogro, mas amassada e descartada sem ponto final (depois que nós, leitores, vemos seu conteúdo). Justapostas com fina ironia pela escritora, as cartas iluminam a proximidade entre o empresário e político rico com a instituição católica, e a manipulação das vidas de

27 Ritmos do Caribe tentam sorrateiramente sacudir a ordem estabelecida: além da "Habanera”, música cubana do século XIX difundida no mundo e adaptada na ária mais popular da ópera Carmen, o conto de Ferré evoca no sobrenome da equilibrista Carmen o popular Merengue, ritmo original da República Dominicana divulgado e dançado no Caribe e na América Latina. 
crianças e jovens dentro de limites rígidos herdados do colonialismo patriarcal (relações sociais, educação, profissão, casamento, etc.). O resultado é a construção literal de um arremedo de vida para Maria de los Angeles no intuito de salvá-la dos perigos diabólicos do "mundo". Preservam-se, assim, os interesses de continuidade, prestígio, influência política e social e, claro, a acumulação de bens da família - e da escola católica, para onde fluem volumosas doações. Maria nunca responde à carta que lhe é enviada pela Madre, recheada de conselhos tradicionais sobre casamento e maternidade.

Além dessas cartas e dos outros tipos de escritos já citados, duas cartas anônimas quebram a cronologia e precedem as demais na estrutura narrativa, inseridas sem preâmbulo na abertura do conto, gerando suspense e atiçando o interesse na leitura. Logo após o título que encabeça o conto, Rosario Ferré inova e surpreende ao substituir o habitual parágrafo de abertura pela transcrição imediata da primeira carta anônima, com a data na primeira linha seguida da saudação ao destinatário e o corpo da carta. A saudação mostra certa familiaridade ao adotar o primeiro nome, Felisberto, ainda que precedido de "Don". Seguem-se as três versôes desse início de carta e conto (aqui identificadas a, b, c), mostrando as variaçóes em datas e apresentação gráfica no original espanhol (1976, 2000, p.149) e nas traduçóes para o inglês publicadas em Vélez (1988, 1997) e em Ferré (1991). Comparemos as versóes:

(a)

Septiembre 28 de 1972

Estimado Don Felisberto:

Se sorprenderá al recibir mi carta.

Na publicação original em espanhol (a), a data da primeira carta anônima, 28 de setembro de 1972, coincide com a gravidez avançada de Maria de los Angeles, já que o anúncio do nascimento do seu filho é de 5 de dezembro de 1972. Próximo ao final do conto, o marido Felisberto revela em carta para o sogro, datada de 30 de maio de 1973, seu sofrimento e perplexidade com as atitudes rebeldes e incompreensíveis da esposa, sobretudo em relação à obsessão pela dança e à rejeição das obrigaçóes conjugais e da maternidade. Sua insatisfação e ira são agravadas pelo recebimento recente de duas cartas 
anônimas (o que parece indicar a hesitação da autora e a retenção das cartas por vários meses, antes de seu envio). Uma após a outra, elas alertam a esse homem "bom" e "bonito", além de "magnata financeiro", sobre o comportamento suspeito de sua esposa que, disfarçada com lenço na cabeça e óculos escuros, faz visitas vespertinas diárias ao quarto $7 \mathrm{~B}$ do Hotel Elisios, lugar barato da cidade. A segunda carta, datada de uma semana depois, traz dados concretos e acusaçóes mais incisivas, inclusive ao dizer que, por não manifestar o devido repúdio, o marido está permitindo que a esposa ande procurando outros homens. Na carta ao sogro, Felisberto declara que verificará no dia seguinte as insinuaçóes de adultério, dizendo-se "destroçado" e temendo "não poder responder por seus próprios atos” (FERRÉ, 2000, p. 183-184). A interrupção nervosa do longo relato e a saída precipitada podem indicar que o desfecho violento se dá nesse mesmo dia, quando os dois, mulher e marido, acabam assassinados.

(b)

DECEMBER 1, 1973

\section{DEAR DON FELISBERTO:}

\section{KNOW YOU'LL BE SURPRISED TO GET THIS LETTER. ${ }^{28}$}

A primeira tradução do conto para o inglês (b) transpóe a data da carta para quase um ano após o nascimento do filho Fabianito e deixa menos tempo entre as datas das duas cartas anônimas (01 e 18 de dezembro) e a reação de Don Felisberto, expressa em carta ao sogro de 20 de dezembro de 1973, interrompida e amassada antes que ele saia para verificar a denúncia recebida in loco. Essa versão do conto destaca graficamente as duas cartas anônimas e também a carta escrita por Felisberto com o uso de letras maiúsculas.

(c)

May 21, 1973

Dear Don Felisberto:

28 Em tradução livre: "Sei que ficará surpreso ao receber esta carta". 
For a few weeks now I've seen your wife go by the window of the beauty parlor where I work as manicure girl. ${ }^{29}$

$\mathrm{Na}$ versão publicada em 1991 (c), todas as cartas inseridas são graficamente destacadas em fonte específica, diferente do Times New Roman usado em outras partes do texto. A data antecipada da primeira carta anônima (e da segunda, datada de 29 de maio) aproxima o clímax, ou o auge da crise silenciosamente vivida por Maria de los Angeles, dos acontecimentos anteriores relatados no texto, como seu casamento e o nascimento do filho (mantidos sempre nas mesmas datas, respectivamente 25 de fevereiro e 05 de novembro de 1972). Por outro lado, há um tempo dilatado entre as datas das cartas anônimas e o movimento de reação registrado por Felisberto em sua carta (datada 20 de dezembro de 1973 nas duas versóes em inglês). Como ele afirma ter recebido as cartas nas duas últimas semanas, ao leitor do conto resta especular sobre as razóes que teriam motivado sua escrita e a hesitação no envio.

Ainda em (c), segunda e última versão em inglês do conto, a primeira carta anônima difere das publicaçóes anteriores ao omitir a certeza da surpresa do leitor/receptor que o emissor enunciava na frase inicial. Agora entra diretamente no assunto com informaçóes sobre si mesmo/a e seu objetivo: é do sexo feminino, trabalha como manicure em um saláo de subsolo, com pequenas janelas para a rua, e promete revelaçóes inquietantes sobre o percurso que anda fazendo a esposa do respeitável destinatário. O suspense criado com a mera insinuação de transgressão e adultério faz jus à tradição do gênero epistolar já marcante em obras do século XVII e XVIII, como afirma Janet Altman: "Em inúmeros romances de cartas [letter novels], o suspense é transferido do nível da ação (tipo de suspense do romance de aventura) para o nível essencial de comunicação da modalidade epistolar" (ALTMAN, 1982, p. 61; destaque original).

Nas três versões de Ferré, as acusaçôes de imoralidade e adultério são contundentes na segunda carta anônima, que cobra do receptor uma resposta à altura de tal ofensa e procura resguardar a manicure-remetente de uma investigação ou perseguição (declarando seu abandono imediato e definitivo do

29 Em tradução livre: "Há algumas semanas vejo sempre sua esposa passando na frente da janela do salão de beleza onde trabalho como manicure”. 
emprego). As cartas dirigem-se ao destinatário, Don Felisberto, como pessoa digna que não merece a traição e a exposição inconsequente da reputação da esposa e da família. A despedida amistosa reitera a caracterização do emissor como alguém bem-intencionado em seu interesse e admiração pelo receptor: "Sinceramente, sua amiga e admiradora". A ironia ressoa na utilizaçáo do padrão comum de despedida epistolar, com o uso da palavra "sinceramente" a sublinhar a veracidade das informaçóes e sentimentos relatados. No corpo da narrativa de Ferré, as duas cartas anônimas precedem a justaposição de trechos em itálico, registrando o fluxo de pensamentos e memórias entrecortadas de Maria, além das outras cartas e dos artigos que contribuem tanto para costurar quanto para fragmentar o texto. Esses fragmentos de formatos e autores diversos misturam versóes irônicas dos fatos e mostram níveis variados e truncados de contaminação da "verdade".

Adaptado e renovado a cada versão, o conto de Ferré se mostra performaticamente flexível e mutante, embora a técnica narrativa se mantenha consistente no suspense, na ironia, e na proeminência dramática assumida pelo silêncio da protagonista. $\mathrm{O}$ aviso a Don Felisberto, expresso no início da primeira carta anônima em "La bella durmiente" (p. 149), parece ser endereçado ao leitor e abranger o caráter inovador e pungente de toda a obra de Ferré: "Se sorprenderá al recibir mi carta.” Por fim, a autoria e a motivação do envio das cartas, insinuadas durante o conto, surpreendem pelo contraste com padróes mais usuais encontrados na literatura, como as que ilustram a primeira parte deste artigo.

Há uma indicação da provável autoria logo no início do conto, mas as pistas são facilmente ignoradas ou esquecidas numa primeira leitura, quando conflitos e personagens ainda são desconhecidos. Embora todos girem em torno do comportamento da protagonista, suas reaçóes podem passar despercebidas ou desfocadas em meio à multiplicidade de vozes e fragmentos. Com ligeiras variaçóes entre as versóes publicadas, um parágrafo curto em terceira pessoa vem logo após a inserçáo de cada carta anônima no conto e descreve minuciosamente as açóes da pessoa que acaba de escrever a carta, dobrando-a, anotando com dificuldade o endereço no envelope, com a mão esquerda e o mesmo lápis usado na carta. No texto em espanhol, o gênero da pessoa não é revelado, já que o pronome pessoal não aparece: "Dobla la carta, la mete en el sobre, escribe la dirección...”(2000, p. 150). A língua inglesa, porém, exige 
o pronome que identifica a autora do sexo feminino: "She folds the letter [...] she scrawls an address..." (1997, p. 13). Segue-se a informação mais importante para a identificação da autoria, um relato curto, pausado, despojado de nervosismo ou emoção, que fará mais sentido quando se tiver lido todo o conto. A mulher que acaba de escrever a carta e fechar o envelope alonga o corpo em frente ao espelho e, na ponta dos pés, começa seus exercícios físicos diários. Maria de los Angeles, protagonista do conto e autora das cartas anônimas, prepara a encenaçáo da própria morte. $\mathrm{O}$ fluxo de pensamentos que encerra o conto de Ferré reflete o estado dilacerado da protagonista, sua profunda divisão interna e o sofrimento extremo sob cobranças e ameaças. A leitura desse trecho mostra-se reveladora e dolorosa:

That ceiling is a mess up there, I told you dancing was forbidden keep insisting on it and I'll break you [...] no please not today Felisberto you'll make me pregnant [...] Oh Lord I don't mind dying but I hate to leave the child forget about dancing [...] no I'm not happy Felisberto you betrayed me that's why I've brought you here so you can see for yourself (FERRÉ, 1991, p. 118-119). ${ }^{30}$

A questão da autoria é fortemente atrelada a gênero no texto de Ferré, já que tanto o conto, como as cartas anônimas que lhe servem de moldura, têm autoria feminina. Significativamente, é o corpo duplicado de Maria de los Angeles Fernandez/Carmen Merengue que se expressa e grita através da dança, ao longo da narrativa. A 'fala' da protagonista se resume às cartas anônimas que, a deduzir pelas pistas deixadas no conto, ela escreve num lugar praticamente invisível, o quarto de hotel barato e escondido onde pratica balé, equilibrismo, e faz sexo com um homem desconhecido (em encontro aparentemente único e longamente premeditado). O local onde as cartas são escritas, cenário do clímax de tensão do conto, faz lembrar a opinião emitida pelo escritor Ítalo Calvino em entrevista de 1982, publicada em The Paris Re-

30 Em tradução livre: "Esse teto aí está uma sujeira, eu te falei que a dança está proibida continua insistindo que vou lhe quebrar [...] não, por favor, hoje não, Felisberto, você vai me engravidar [...] Oh Senhor não me importo de morrer mas odeio deixar a criança esquece da dança [...] não, não sou feliz, Felisberto, você me traiu; é por isso que eu lhe trouxe aqui;assim você pode ver com seus olhos. A língua portuguesa realça a proximidade irônica de "não feliz" e "Felisberto". 
view em $1992^{31}$ e citada por Arfuch. ${ }^{32}$ Em resposta à pergunta se ele "poderia escrever num quarto de hotel", Calvino responde: "Eu costumava dizer que um quarto de hotel era o espaço ideal: vazio, anônimo". Um quarto anônimo, num hotel barato igualmente invisível e sem respeitabilidade, como se vê em "La bella durmiente", sublinha ainda mais o anonimato das cartas e a solidão dilacerada de quem as escreveu e enviou.

$\mathrm{O}$ ato de transgressão trágica e radical de María de los Ángeles faz-se primordialmente no silêncio e na escrita, efeito buscado também por Ferré em sua obra. Os personagens são todos porto-riquenhos, originários de um lugar marcado por ocupaçóes sucessivas e pela falta de autonomia, mas Maria tem a identidade negada e triturada pelo sistema patriarcal e pelas mulheres que o apoiam. Parece pertinente o comentário de Linda Kauffman (ao focalizar cartas em As três Marias): "A mulher é objeto de conquista, mesmo para os homens que são, eles mesmos, colonizados, seja no México ou em Portugal..." Uma estratégia de resistência feminina é expor o silêncio fatal, "a experiência da colonização como privação da linguagem”, do respeito próprio e de imagens positivas. Como assevera uma das Marias, citada por Kauffman, estar calada não significa consentir, como o provérbio apregoa; na verdade, quem cala diverge. ${ }^{33}$

María de los Ángeles, fadada ao silêncio e à obediência, dá mostras de resistência ao fugir do palco, ao ignorar pressóes e ao insistir em seu desejo. No final, a agressão física e psicológica a leva a rebelar-se silenciosamente, em espaço escondido e marginal, transformando-se em Carmen Merengue, com o cabelo vermelho, a maquilagem pesada e os cílios postiços. Permite, de certa forma, que esta outra, seu duplo, agrida e resista ao poder patriarcal e cristão do qual, por si só, María de los Ángeles não conseguia libertar-se. A sombra do pai, forte, solene e incestuosa, preside a identificação trágica da

31 CALVINO, Ítalo. Interview: The art of fiction n. 130. The Paris Review 124, outono 1992. Entrevista concedida a W.Weaver e D.Pettigrew. http://www.theparisreview.org/interviews/2027/the-art-of-fiction-no-130-italo-calvino\&usg=ALkJrhhkphSg6yOtrVkoJKYdpI tqLt4d5A. 20/02/2012.

32 ARFUCH, Leonor. O espaço biográfico: dilemas da subjetividade contemporânea. Tradução Paloma Vidal. Rio de Janeiro: EdUERJ, 2010. p. 220.

33 KAUFFMAN, Linda S. Discourses of desire: gender, genre, and epistolary fictions. Ithaca \& London: Cornell University, 1986. p. 292. 
filha María com a amante Carmen. Para que os papéis de gênero e fronteiras de raça e classe possam ser preservadas, a jovem termina assassinada como a sensual Carmen, que habita o romance de Merimée, a ópera de Bizet e a fantasia universal. Os espaços transgressores são consentidos apenas à medida que ofereçam algum consolo aos oprimidos e, principalmente, sustentem o desejo e prazer dos poderosos, como o circo e o teatro mambembe, os cultos miscigenados, a casa da amante e os locais de prostituição.

No conto de Ferré, um raro trecho em terceira pessoa segue-se à carta de Felisberto (na qual ele anuncia sua raiva com as cartas anônimas e a situação provocada pela mulher); é talvez o único trecho com uma narrativa mais linear (embora também interrompida, sem ponto final). O narrador faz um relato dos momentos finais de María (mais confiável que o da carta de Don Fabiano, um ano depois?), quando ela completa seu intento: no quarto com persianas sujas e quebradas, um homem ressona no sofá sobre ela, ambos nus. Ela consegue deslizar seu corpo, coloca as sapatilhas e sobe na corda de nylon já esticada de um lado a outro do quarto. Pé ante pé, cuidadosamente, equilibra-se como Carmen, sabendo que ... a porta se abre com força...

$\mathrm{Na}$ modernidade de sua linguagem e no tom sinistro e cortante do relato, Rosario Ferré faz lembrar as criativas inserçóes epistolares e a mistura de 'realidade' e fantasia na obra de Julio Cortázar (na "Carta a una señorita en París”, por exemplo, entre outros contos). ${ }^{34}$ Alinha-se com Virginia Woolf ao canalizar raiva e revolta para a escrita, transformando-as em ironia, como a própria escritora explica: "A ironia consiste precisamente na arte de dissimular a ira e regular o fio cortante da linguagem para, desta forma, conseguir um discurso de maior efeito". ${ }^{35}$ Subvertendo expectativas com o riso amargo e denunciador em Papeles de Pandora, Ferré alcança uma influência incontestável atestada por Ana Lydia Vega, escritora também porto-riquenha efeminista. Por desafiar a hegemonia masculina e as divisóes de classe e raça no cenário literário do país,

34 CORTÁZAR, Julio. Cuentos Completos. Madrid: Alfaguara, 1994. As possibilidades intertextuais não serão elaboradas no presente artigo.

35 In: FERRÉ, Rosario. De la ira a la ironía, o sobre cómo atemperar el acero candente del discurso. Sitio a Eros. México: Joaquín Mortiz, 1980. p.191-98. http://www.sololiteratura. com/fer/ferdelaira.htm. 23/10/2009. No original: "La ira movió, durante siglos, a innumerables mujeres a escribir sus textos. [...] La ironía consiste precisamente en el arte de disimular la ira de atemperar el acero lingüístico para lograr con él un discurso más efectivo". 
diz Vega (1994) "sua primeira publicação foi considerada um escândalo. Ali estava a filha de um ex-governador, uma mulher rica que quebrou as convenções de sua classe." A publicaçâo atraiu "imediatamente a atenção nacional", abrindo portas para outras escritoras e destruindo "as barreiras existentes". ${ }^{36}$

O título original da coletânea de Ferré na qual o conto se insere, Papeles de Pandora (1976), traz à cena o arquétipo feminino de Pandora e reitera o jogo de papéis herdados, resistidos e reescritos por personagens femininas. ${ }^{37}$ Conjugando estilo literário com a cultura e a história de Porto Rico, o conto pode ser lido como paródia irônica e amarga da situação de subalternidade feminina e, também, das tradiçóes vigentes na ilha. Ainda que controladas por um poder externo e superior, as elites de homens brancos se sucedem no controle sexual, racial, cultural, político e econômico, enquanto marginalizam espaços hibridizados, instáveis e impuros. Com ironia ferina, o texto retoma temas e ingredientes típicos das "ficçóes de fundação" que ecoam na memória das Américas, ${ }^{38}$ problematizando e desestabilizando as premissas dessa literatura inaugural que tentava legitimar a nação apoiando-se nas raízes e laços de família do estado patriarcal burguês. A respeito da produção de autoria feminina na últimas décadas em Porto Rico, Diana Vélez observa que, com a redefinição de "mulher" e a multiplicidade de vozes narrativas, observam-se "violações de muitos códigos" e "subversões de poder". ${ }^{39}$ Dessa maneira, aos poucos, os papéis de Pandora, mulher primeira desobediente e rebelde, vão-se multiplicando e transformando na escrita, anunciando a esperança de tempos e espaços menos punitivos e mais livres.

36 VEGA, Ana Lydia. Women and writing in Puerto Rico: an interview. Entrevista concedida a C.Lopez Springfield e E.Hernandez. Callaloo, Johns Hopkins University, June 22, 1994 (Special Issue: Puerto Rican Women Writers). http://www.accessmylibrary.com/article1G1-16309326/women-and-writing-puerto.html. 26/10/2009.

37 Pandora significa "a detentora de todos os dons", adornada por presentes de deuses e deusas. Mas, para Hesíodo (Teogonia), a primeira mulher era um "mal tão belo"; como Eva, a causa dos males que afligem o homem. Segundo o mito, ao abrir a jarra que guardava as mazelas da humanidade, Pandora espalhou esses males (ou bens, segundo outras versóes), só ficando na jarra a esperança. BRANDÃO, Junito. Dicionário Mítico-etimológico: Mitologia grega. 3 ed. Petrópolis, RJ: Vozes, 1991. v. II. p.234-235.

38 SOMMER, Dóris. Fiç̧ões de fundação: os romances nacionais da América Latina. Belo Horizonte: UFMG, 2004.

39 VÉLEZ, Diana L. Introduction. In:___. (Ed.). Reclaiming Medusa: short-stories by contemporary Puerto Rican women. Rev. Ed. San Francisco: Aunt Lute, 1997. p. iii. 
Por outro lado, o jogo epistolar criado por Ferré afasta-se radicalmente do tipo de escrita sentimental epistolar em romances considerados 'tipicamente femininos' e descartados pela historiografia literária que, por conseguinte, estabeleceu uma associação pejorativa e duradoura entre mulheres e cartas. Em reversão irônica, Ferré parece remeter ao argumento de Cesare Lombroso (1896), lembrado por Howard Bloch: "Se as mulheres precisarem escrever, recomenda-se que escrevam cartas, tidas como a forma escrita da conversaçáo, o que se 'ajusta ao caráter delas, e, mais uma vez, satisfaz sua necessidade de falar"”. ${ }^{40}$ De maneira trágica, Maria de los Angeles precisa, profunda e sinceramente, expressar-se, dançar, falar de si, escrever, e escreve cartas.

Os escritos fundadores do continente americano, por outro lado, são documentos de autoria masculina, considerados os primeiros textos da "literatura das Américas”. Esses relatos da conquista e ocupação são textos que adotaram a forma de diários ou cartas e que "nomeavam o mundo que se gestava diante dos olhos do império", como expressa Elena Palmero González (2006, p. 25) ${ }^{41}$ usando "a eloquente metáfora de Mary Louise Pratt". ${ }^{42}$ Narrar no feminino, portanto, escrevendo cartas e diários, anônimos ou assinados, significa interferir no discurso histórico e literário da nação e do continente.

\title{
"SINCERELY YOURS": ANONYMOUS LETTERS IN ROSARIO FERRÉ
}

\begin{abstract}
After brief analysis of the epistolary genre and the specificity of the anonymous letter illustrated with examples from Brazilian literature, this study focuses on letters inserted by Rosario Ferré in the short-story "La bella durmiente”/“Sleeping Beauty”(1976), combining tex-
\end{abstract}

40 BLOCH, R. Howard. Misoginia medieval e a invenção do amor romântico ocidental. Rio de Janeiro: Editora 34, 1995. p. 37-38.

41 PALMERO GONZÁLEZ, Elena. Poéticas del viaje en la narrativa de la alta modernidad latinoamericana: Los pasos perdidos, de A. Carpentier. Contexto- Revista Anual de Estudios Literarios, Universidad de Los Andes, Táchira, v. 10, n. 12, p. 23-42, 2006.

42 PRATT, Mary Louise. Os olhos do império: relatos de viagem e transculturação. Tradução Jézio H. B.Guerra. Bauru: Ed. da Universidade do Sagrado Coração, 1999. 
tual and sociocultural analysis, and associating anonymous letters both to women's condition and the Puerto-Rican marginal situation as nation/state.

KEYWORDS: “La bella durmiente”, anonymous letter, women.

Recebido em: 16/03/12

Aprovado em: 25/11/12 